\title{
An Empirical Study on the Relationship between Financial Development, Economic Growth and Income Disparity in China
}

\author{
Caiming Liu \\ Shanghai Academy, Shanghai University, Shanghai, China \\ mingmingliu@126.com
}

Keywords: Financial development; Economic growth; Income gap

\begin{abstract}
Urban and rural development and reduce urban-rural income gap is a hot topic of economic research, interaction between financial development, economic growth and income inequality mechanism of great significance for the study of the problem. In this paper, by constructing the vector error correction model(VEC), and makes an empirical study on the relationship between financial development, economic growth and income gap in China from 1990 to 2016. The study found that financial development, economic growth and income gap have the long-term equilibrium relationship; financial development will expand the income gap, and financial development is resulted widening income gap of Granger reasons, the expansion of the income gap to a certain extent, inhibited the financial development, however, this inhibition is lagging; economic growth has widened the income gap, and the income gap is the reason for the economic growth of Granger, Indicating that the income gap contributed to economic growth; economic growth in the early inhibition of financial development, but in the long run, economic growth to promote financial development, and economic growth is the financial development of Granger reasons.
\end{abstract}

\section{Introduction}

As the core of modern economy, financial development has a positive effect on economic development. Financial development mainly affects the economy through the total amount of financial assets, financial development structure and financial development efficiency. At the same time, China's financial development level there is a clear regional gap, mainly in the rural financial development level is far behind the level of urban and rural financial development, and this gap is showing an expanding trend, this gap leads to the direct consequence of the widening income gap between urban and rural areas. So, financial development, economic growth and income gap, whether there is a mechanism of action? What about the outcome?

\section{The Literature Review}

Although there are many studies on financial development and economic growth and income gap at home and abroad, there are differences in the conclusions drawn. This paper discusses the research conclusions and research results at home and abroad from the following three aspects.

Classical economists, such as Adam Smith ${ }^{[1]}$, have long recognized that banks can create wealth through credit, promote the flow of social real capital, and promote economic growth. King and Levine $^{[2]}$ crossed and regained the relationship between financial development and economic growth in more than 80 countries, confirming that there was a strong positive correlation between financial development and economic growth, and he believes that the financial system through the savings mobilization, asset allocation and financial services and other functions to promote capital accumulation and technological innovation in order to achieve economic growth. At the same time, some foreign scholars believe that financial development has an inhibitory effect on economic growth. The study of Show ES ${ }^{[3]}$ and Mackinnon ${ }^{[4]}$ shows that economic development is inhibited by the low supply and demand elasticity in economic structure due to insufficient supply and demand in the financial market. The effects of financial development on the economy are particularly prominent in many developing countries and in poor areas. Robert Lucas ${ }^{[5]}$ argues that 
the role of finance in economic development is overemphasized, and endogenous technological progress is the main factor driving economic growth. He believes that economic and financial development in their respective directions, there is no causal relationship.

Greenwood and Jovanovic ${ }^{[6]}$ first proposed the establishment of a dynamic model to discuss the relationship between economic growth, financial development and income distribution. At the beginning of economic development, the lower level of financial development expanded the income distribution gap. But in the long run, the income gap will shrink with the growth of economic growth and financial development until it converges to equilibrium. In contrast to Greenwood and Jovanovic's conclusions, Galor and Zeira ${ }^{[7]}$ found that the lower the level of financial development, the higher the cost of financial intermediation, and the lack of financial support, which further exacerbated the income gap between rich and poor. At the same time, some scholars believe that financial development can narrow the income gap.

Barro ${ }^{[8]}$ examined the non-linear relationship between the income gap and the level of economic development. The explanatory variables included not only the income gap, but also the interaction between the income gap and the level of economic development, and found that income inequality in developed countries. There is a positive correlation between economic growth, and in developing countries, there is a negative correlation between the two.

\section{Empirical Research}

Selection of Economic Variables. Financial development. This paper uses the financial scale of development - the total amount of financial assets / GDP to measure the level of financial development (FA).In many research literature, the scale of financial development is often measured by the McI's index, M2, the proportion of GDP (Mckinnon, 1973). However, there are many shortcomings in the data description of the Markovian index, mainly M2 as the broad money supply It is difficult to define and measure caliber. Arestis et al. (2001) designed the bank's share of GDP as a measure of the level of financial development. The total amount of financial assets / GDP is a measure of the level of financial development. It is a measure of Wang Yi (2002) in the measurement of financial consolidation in China by financial indicators.

Economic Growth. Domestic related research on the use of gross domestic product (GDP) or per capita gross national product (PGDP) to measure economic growth. For the economic growth indicators, since the per capita GDP data is more accurate than the GDP data, for the above reasons, this paper uses the logarithmic form of gross domestic product (lnPGDP) to measure the level of economic growth.

Income Gap. According to the existing literature, the domestic study of commonly used urban per capita disposable income and rural per capita net income ratio to measure the urban-rural income gap, but also literature that the Gini coefficient is a reflection of a country's urban and rural income gap between the basic indicators. Because the calculation of Gini coefficient is relatively complex, this paper chooses the ratio of urban per capita disposable income and rural per capita net income $(\mathrm{G})$ to measure the income gap.

Data Description. We collect annual data on economic growth and income disparity indicators in the China Statistical Yearbook (2016) and the National Bureau of Statistics, and download and finalize the annual financial assets in the flush database. As the country in the late $80 \mathrm{~s}$, stock financing issue began to be used, corporate bonds began to issue, the rapid expansion of the scale of financial assets, so we select the 1990 - 2016 data for empirical research.

The Smoothness of Time Series Test. In this paper, the Augmented Dickey-Fuller(ADF) unit root test method was used to test the stability of these three variables. Since the sample data is a nonzero mean, the ADF check contains constant terms. The results of the test are shown in Table 1: FA, lnPGDP and G are non-stationary sequences at 5\% significance level, but the first order difference of FA, lnPGDP and $\mathrm{G}$ is a stationary sequence at the significance level of $5 \%$. Thus, these three sequences are first-order monotonous. 
Table 1 ADF unit root test for each sequence of variables

\begin{tabular}{|l|l|l|l|l|}
\hline Variable & Test form & ADF Statistics & $\begin{array}{l}\text { Critical } \\
\text { value[5\%] }\end{array}$ & P value \\
\hline FA & $(\mathrm{C}, 2)$ & -3.545328 & -3.733200 & 0.0349 \\
\hline$\Delta$ FA & $(\mathrm{C}, 2)$ & -7.149734 & -3.690814 & 0.0001 \\
\hline $\ln$ PGDP & $(\mathrm{C}, 2)$ & -2.984190 & -3.673616 & 0.1614 \\
\hline$\Delta \ln$ PGDP & $(\mathrm{C}, 2)$ & -6.353303 & -3.673616 & 0.0003 \\
\hline $\mathrm{G}$ & $(\mathrm{C}, 2)$ & -3.452673 & -3.644963 & 0.0712 \\
\hline$\Delta \mathrm{G}$ & $(\mathrm{C}, 2)$ & -5.056837 & -3.673616 & 0.0037 \\
\hline
\end{tabular}

Note: The test form $(\mathrm{C}, \mathrm{K})$ indicates whether the unit root test contains the constant term $(\mathrm{C})$ and the lag order $(\mathrm{K})$, respectively. The lag order is determined by the AIC and SC information criteria.

Cointegration test and VEC model construction. The cointegration test of Johansen can only be carried out under the condition that the order is stable, and the cointegration test can judge whether there is a long-term relationship between sequences. The three sequences of FA, InPGDP and $\mathrm{G}$ are first order, and the optimal lag order is 2 according to AIC and SC information criterion.

Table 2 Johansen cointegration test results

\begin{tabular}{|l|l|l|l|c|}
\hline $\begin{array}{l}\text { Hypothesized } \\
\text { No. of CE(s) }\end{array}$ & Eigenvalue & Trace Statistic & $\begin{array}{l}0.05 \text { Critical } \\
\text { Value }\end{array}$ & Prob. ${ }^{* *}$ \\
\hline None $*$ & 0.6856250697 & 34.149779304 & 29.797073340 & 0.014807 \\
\hline At most 1 & 0.2921165411 & 8.6920621812 & 15.494712875 & 0.394644 \\
\hline At most 2 & 0.0484070702 & 1.0915944701 & 3.8414655009 & 0.296117 \\
\hline
\end{tabular}

The results of Table 2 show that, at the 5\% significance level, the $\mathrm{T}$ statistic test and the maximum eigenvalue statistic test reject the original hypothesis that there is no cointegration relationship and accept the original hypothesis that there is at least one cointegration equation. Thus, at the 5\% significance level, there is a cointegration relationship between the three variables of FA, $\ln P G D P$ and $G$, and there exists a cointegration equation between the variables.

The following vector error correction model is established. The concrete results are as follows: $\mathrm{D}(\mathrm{FA})=-1.528020 \mathrm{ECM}+0.327128 \mathrm{D}\left(F A_{t-1}\right)+0.379597 D\left(F A_{t-2}\right)$

$$
\begin{aligned}
& -8.374252 D\left(\ln P G D P_{t-1}\right)+2.489621 D\left(\ln P G D P_{t-2}\right)+1.473538 D\left(G_{t-1}\right) \\
& +0.100049 D\left(G_{t-2}\right)+0.332492 \\
\mathrm{D}(\ln P G D P)= & -0.0623 \mathrm{ECM}+0.040416 \mathrm{D}\left(F A_{t-1}\right)-0.016239 \mathrm{D}\left(F A_{t-2}\right) \\
& +0.944811 \mathrm{D}\left(\ln P G D P_{t-1}\right)-0.501409 \mathrm{D}\left(\ln P G D P_{t-2}\right)+0.085226 \mathrm{D}\left(G_{t-1}\right) \\
& +0.030324 \mathrm{D}\left(G_{t-2}\right)+0.027062 \\
\mathrm{D}(\mathrm{G})=0.497672 \mathrm{ECM}-0.366722 \mathrm{D}\left(F A_{t-1}\right)-0.073076 \mathrm{D}\left(F A_{t-2}\right) & \\
& +0.499324 \mathrm{D}\left(\ln P G D P_{t-1}\right)+0.060697 \mathrm{D}\left(\ln P G D P_{t-2}\right)+0.670451 \mathrm{D}\left(G_{t-1}\right) \\
& -0.585387 \mathrm{D}\left(G_{t-2}\right)+0.024137
\end{aligned}
$$

Among them, the error correction term is

$\mathrm{ECM}=F A_{t-1}-1.368214 \ln P G D P_{t-1}-0.545378 G_{t-1}+5.120629$

Variance Decomposition. The variance decomposition is the ratio of the standard deviation of the predicted residuals affected by the impact of different messages, that is, the contribution of the corresponding endogenous variables to the standard deviation. 
Table 3 FA, lnPGDP and G variance decomposition

\begin{tabular}{|c|c|c|c|c|}
\hline \multicolumn{5}{|c|}{ Variance Decomposition of FA } \\
\hline Period & S.E. & FA & LNPGDP & $\mathbf{G}$ \\
\hline 1 & 0.199901 & 100.0000 & 0.000000 & 0.000000 \\
\hline 2 & 0.231078 & 76.42825 & 11.58886 & 11.98289 \\
\hline 3 & 0.236107 & 74.35033 & 13.75875 & 11.89110 \\
\hline 4 & 0.246172 & 74.62788 & 14.11961 & 11.25251 \\
\hline 5 & 0.248944 & 73.27181 & 15.58206 & 11.14614 \\
\hline 6 & 0.249325 & 73.15861 & 15.53793 & 11.30166 \\
\hline 7 & 0.250475 & 73.11961 & 15.65820 & 11.22219 \\
\hline 8 & 0.252056 & 72.23887 & 16.01270 & 11.74843 \\
\hline 9 & 0.255224 & 71.03425 & 16.79103 & 12.17472 \\
\hline 10 & 0.259506 & 69.74738 & 17.21865 & 13.03397 \\
\hline \multicolumn{5}{|c|}{ Variance Decomposition of LNPGDP } \\
\hline Period & S.E. & FA & LNPGDP & $\mathbf{G}$ \\
\hline 1 & 0.014720 & 3.082644 & 96.91736 & 0.000000 \\
\hline 2 & 0.030812 & 8.980581 & 83.18394 & 7.835474 \\
\hline 3 & 0.046184 & 7.835459 & 72.43341 & 19.73113 \\
\hline 4 & 0.060657 & 11.18780 & 63.27511 & 25.53709 \\
\hline 5 & 0.072737 & 15.62424 & 54.37593 & 29.99983 \\
\hline 6 & 0.081286 & 19.08191 & 47.55584 & 33.36225 \\
\hline 7 & 0.087007 & 22.49672 & 42.73267 & 34.77061 \\
\hline 8 & 0.090596 & 25.18979 & 39.62455 & 35.18566 \\
\hline 9 & 0.092655 & 26.93307 & 37.89578 & 35.17115 \\
\hline 10 & 0.093863 & 28.08563 & 36.93321 & 34.98116 \\
\hline \multicolumn{5}{|c|}{ Variance Decomposition of G } \\
\hline Period & S.E. & FA & LNPGDP & $\mathbf{G}$ \\
\hline 1 & 0.065919 & 21.38606 & 1.282928 & 77.33101 \\
\hline 2 & 0.106524 & 24.45081 & 1.495462 & 74.05373 \\
\hline 3 & 0.140460 & 34.94816 & 7.945527 & 57.10631 \\
\hline 4 & 0.168133 & 34.29483 & 22.27166 & 43.43350 \\
\hline 5 & 0.191161 & 29.39246 & 37.00558 & 33.60196 \\
\hline 6 & 0.210518 & 24.78870 & 46.07050 & 29.14080 \\
\hline 7 & 0.224253 & 21.87290 & 49.73674 & 28.39036 \\
\hline 8 & 0.231808 & 20.91912 & 49.86639 & 29.21449 \\
\hline 9 & 0.234591 & 20.96794 & 49.06449 & 29.96757 \\
\hline 10 & 0.235445 & 21.15263 & 48.83810 & 30.00927 \\
\hline
\end{tabular}

The results of the variance decomposition show that the predicted standard deviation of FA is from $100 \%$ to $69.75 \%$, which is caused by the residual impact and continues to play a major role in the tenth period,and lnPGDP and G residuals on the impact of FA is very small, to the tenth period is still not reached $20 \%$.The expected standard deviation of lnPGDP is $96.92 \%-36.93 \%$, which is carried by itself and continues into the tenth period,and the residual effect of FA on the lnPGDP impact to the tenth period to $28.09 \%$, G residual on the impact of lnPGDP to the tenth period only reached $34.98 \%$. Therefore, by the tenth period, the FA residuals have a greater contribution to the standard deviation of lnPGDP.G standard deviation from $77.33 \%-30.01 \%$ by its own bearing, and continued to the tenth period, and FA residuals on the impact of $\mathrm{G}$ to the tenth period to $21.15 \%$, lnPGDP residual impact on the impact of $G$ to the tenth Period to $48.84 \%$, so lnPGDP residual difference on the $\mathrm{G}$ standard deviation of the larger.

Granger Causality Test. At the 5\% significance level, the lag order is 2, the original hypothesis lnpgdp is not the Granger cause of the FA, the FA is not the Granger cause of $G$ and the Granger reason of $\mathrm{G}$ is not lnpgdp, Indicating that economic growth is the financial development of Granger 
reasons, financial development is the income gap of Granger causes and income gap is the economic growth of Granger reasons.

Table 4 Granger causality test for FA, lnPGDP and G relations

\begin{tabular}{|c|c|c|c|}
\hline Null Hypothesis & Obs & F-Statistic & Prob. \\
\hline $\begin{array}{l}\text { LNPGDP does not } \text { Granger } \\
\text { Cause FA }\end{array}$ & 25 & 4.09197 & 0.0354 \\
\hline $\begin{array}{l}\text { FA does not Granger Cause } \\
\text { LNPGDP }\end{array}$ & & 2.94171 & 0.0800 \\
\hline G does not Granger Cause FA & 25 & 0.01599 & 0.9842 \\
\hline FA does not Granger Cause $\mathrm{G}$ & & 4.62536 & 0.0249 \\
\hline $\begin{array}{l}\text { G does not Granger Cause } \\
\text { LNPGDP }\end{array}$ & 25 & 6.35649 & 0.0087 \\
\hline $\begin{array}{l}\text { LNPGDP does not } \text { Granger } \\
\text { Cause G }\end{array}$ & & 2.94906 & 0.0795 \\
\hline
\end{tabular}

\section{Conclusions and Recommendations}

Through the above analysis, we can draw the following conclusions. First, the relationship between financial development and income gap. There is a long-term relationship between financial development and income disparity. Financial development will expand the income gap to a certain extent, this change will be over time U-shaped development trend, and financial develop ment is the widening income gap Granger reasons. While the expansion of the income gap to a certain extent, inhibited the development of finance, but the inhibition has lagged.

Second, the relationship between economic growth and income gap. There is also a long-term relationship between economic growth and income disparity. On the one hand, economic growth has increased the income gap to a certain extent; on the other hand, the income gap has also contributed to economic growth, and the income gap is the Granger cause of economic growth, indicating that a modest income gap stimulates economic growth.

Third, the relationship between financial development and economic growth. There is a long-term relationship between economic growth and financial development. Economic growth in the early inhibition of financial development, but in the long run, economic growth to promote financial development, and economic growth is the financial development of Granger reasons. However, in China, the role of financial development in promoting economic growth is not yet obvious.

In View of the Conclusion of this Paper, the Following Suggestions are Made. First, moderate relaxation of financial controls. Reduce the market players to enter the financial market to protect the social security of each of the main financial power of the economy, the formation of free and open financial markets, so that everyone free access to financial markets.

The second is to promote competition in the financial industry. Through financial openness, so that more foreign financial institutions to enter China, especially in financial and rural areas, increase the supply of rural financial services.

Third, vigorously develop small and medium-sized financial institutions in rural areas, China's rural economy is still a small peasant economy, the relative banks, small and medium-sized banks in small-scale farmers and small and medium enterprises to provide financing services on a more comparative advantage, rural appropriate financial institutions should Small and medium-sized institutions, the ideal amount of rural institutions should be able to these small and medium-sized farmers and enterprises to provide adequate financial services.

\section{References}

[1] Adam Smith. The nature and causes of national wealth [M]. Shanghai: Shanghai Sanlian 
bookstore, 1997.

[2] King R, Levine R. Finance and Growth: Schumpeter might be right [J]. Quarterly Journal of Economics, 1993, 108 (3): 688-722.

[3] Show E S. Financial Deepening in Economic Growth [M]. New York :: Oxford University Press, 1973.

[4] Mackinnon R I. Money and Capital in Economic Development [M]. Washington DC: Brooking Institute, 1973.

[5] Robert Lucas. On the mechanics of economic development [J]. Journal of Monetary Economics, 1998, (22): 3-42.

[6] Greenwood Jeremy and Jovanovic Boyan. Financial development, growth and the distribution of income[J]. Journal of political economy, 1990, 98(5): 1076-1107.

[7] Galor oded, Zeira Joseph. Income distribution and macroeconomics[J].Review of Economic Studies, 1993, 60(1): 35-52.

[8] Barro RJ. Inequality and growth in a panel of counties[J].Journal of Economic Growth, 2000(5): 5 